\title{
Response of Growth and Yield Components of Sweet Pepper to Tow Different Kinds of Fertilizers under Green House Conditions in Jordan
}

\author{
Hussein Hussein Alhrout ${ }^{1}$ \\ ${ }^{1}$ Department of Medical Allied Sciences, Al-Balqa Applied University, Zarka University College, Zarka, Jordan \\ Correspondence: Hussein Hussein Alhrout, Department of Medical Allied Sciences, Al-Balqa Applied University, \\ Zarka University College, Zarka, Jordan. E-mail: hhroot66@yahoo.com
}

Received: June 20, 2017

Accepted: August 26, $2017 \quad$ Online Published: September 15, 2017

doi:10.5539/jas.v9n10p265

URL: https://doi.org/10.5539/jas.v9n10p265

\begin{abstract}
Intensive agriculture is a farming system characterized by a lot use of input, causing a harm stress on the environment, as well as high price of inorganic fertilizers discouraged some farmers in Jordan to apply fertilizers to their crops. The objective of this study was to investigate the impact of chicken manure and NPK on growth and yield of sweet pepper (Caspicum annum L.), A greenhouse experiment was conducted at Albalqa applied university research station in Jordan using randomized complete block design (RCBD) replicated four times. Three treatments were used using Randomized Complete Block Design (RCBD) with four replications: control (without fertilizer), chicken manure at the rate of $15 \mathrm{t} / \mathrm{ha}$, and NPK (15:15:30) with trace elements at $100 \mathrm{Kg} / \mathrm{ha}$. We evaluated plant height $(\mathrm{cm})$, leaves number per plant, number of days to $50 \%$ flowering, fruit number per plant, fruit length, yield of fruit per plant $(\mathrm{kg})$, and yield of fruit per hectare $(\mathrm{t} / \mathrm{ha})$. Treatments showed significant differences between. The NPK treatment gave the highest plant height $(\mathrm{cm})$, leaves number per plant, fruits number per plant, yield of fruits per plant $(\mathrm{kg})$, and yield of fruits per hectare $(\mathrm{t} / \mathrm{ha})$.
\end{abstract}

Keywords: Capsicum annuum L., chicken manure, NPK, Solanacea

\section{Introduction}

Sweet pepper (Capsicum annuum L.) belongs to the solanaceous family and can be grown throughout the year (Kabura et al., 2008). The crop is ranked third most important vegetable crop after tomato and onion in the world (Islam et al., 2011; Belel et al., 2011).

Capsicum consists of approximately twenty-two wild species and five domesticated species. The five domesticated specie include, $C$. annum L., C. baccatum L., C. chinensis L., C. pubescens L., and C. frutescens L., (Bosland \& Votava, 2000). They include mild non pungent (sweet) varieties which are longer and have thicker flesh than the pungent ones (Aliyu et al., 1996).

Pepper like other vegetable crops contributes nutritionally to the human diet. It is rich in nutrient that may be lacking in other food materials thereby making it more palatable and hence improves food intake and digestion. Sweet pepper also known as bell pepper can be cooked or eaten as raw salad. The leaves are also consumed as salad in soup or eaten with rice. It was also discovered to be a good source of medicinal preparation for black vomit, gout and paralysis (Khan et al., 2010). Juroszek and Tsai (2009) reported that sweet pepper fruits are good sources of many essential nutrients, including vitamins A, C, and E, carotenoids, minerals (e.g., calcium and iron), and other secondary plant compounds.

The crop responds to both organic and inorganic fertilizers and has been shown to respond positively to nitrogen and phosphorus fertilizers (Aliyu, 2002).

The use of organic and inorganic fertilizers has amassed a great significance in recent years in vegetable production for two reasons. Firstly, the need for enhanced sustainable increase in production; and per hectare yield of vegetables requires an increased amount of nutrients. Secondly, the results of a many experiments on organic and chemical fertilizers managed in many countries detect that inorganic fertilizer alone cannot sustain productivity of soils heavy cropping system (Khan et al., 2010). Whereas the use of intensive artificial fertilizer in agriculture caused so many health problems and environmental pollution. To decrease and remove the reverse impacts of artificial fertilizers and pesticides on human health and environment, modern practices of agriculture 
were sophisticated in the so-called organic agriculture, ecological agriculture or agricultural sustainability (Malgorzata \& Georgios, 2008).

Arising from the need to increase production of this crop, especially under irrigated cropping condition for all year round supply of the commodity thereby enhancing food security, necessitates this work. There is also the need for use of high yielding, pest and disease resistant varieties to increase the crop yield. In order to obtain high production of sweet pepper, there is the need to augment the nutrient conditions of the soil to meet the crop requirement and maintain the fertility conditions of the soil. One of the methods to increase the nutrient content is by supporting the nutrient content with organic materials such as poultry dung, with or without inorganic fertilizers (Dauda et al., 2008). Poultry dung is relatively resistant to microbial declination (Dauda et al., 2005). Poultry manure has high concentrations of nutrients like nitrogen, phosphorus, calcium and magnesium than other forms of organic manure (Aliyu, 2000).

Sweet pepper is an important crop in Jordan, it is usually produced in Jordan valley, and most of Jordanian people use it as a food, spices and other uses.

Jordan export many vegetables like tomato, potato, cucumber, hot and sweet peppers to other countries especially Gulf countries, which contributes in increasing national income.

On the other hand sweet pepper needs nutrient elements to grow well and increase its productivity, many Jordanian farmers are using organic and inorganic fertilizers to increase their yield and this increase the cost of agricultural input specially when they use inorganic fertilizers, in this experiment we focused on the farmers problems to help them to solve these problems.

\section{Materials and Methods}

\subsection{Experimental Site}

The experiment was conducted in green house at research station of agricultural technology college, Albalqa applied university in Alsalt northern west of Amman, Jordan, during summer season 2015.

\subsection{Treatments, Experimental Design and Plot Size}

Three treatments were used: control (without fertilizer), chicken manure at rate of $15 \mathrm{t} / \mathrm{ha}$, and NPK (15:15:30) with trace elements at $100 \mathrm{Kg} / \mathrm{ha}$. Treatment combinations set in a randomized complete block design (RCBD) with four replications. The plot size was $3 \times 4\left(12 \mathrm{~m}^{2}\right)$; each plot had twenty plants planted in plastic pots, the pot diameter is $50 \mathrm{~cm}$, and each four pots represent $1 \mathrm{~m}^{2}$.

\subsection{Soil Preparation, Fertilizer Application, and Planting}

The soil samples were randomly collected from depth of 0-30 cm across the experimental site during 2015 dry season and thoroughly mixed, and sieved using $2 \mathrm{~mm}$ mesh sieve and later analyzed for physicochemical properties (Table 1), chicken manure was mixed with soil before planting. The pots were filled with soil samples and chemical fertilizer was applied at two equal split doses, first at planting time and the second after six weeks of planting. The pots irrigated and one seedling was planted in each pot, the plants irrigated by drip irrigation when needed.

Table 1. Physical and chemical properties of experimental soil

\begin{tabular}{|c|c|c|c|c|c|c|c|c|}
\hline \multicolumn{2}{|c|}{ Extracts } & \multicolumn{2}{|c|}{ ppm } & \multicolumn{4}{|c|}{$\%$} & \multirow{2}{*}{ Texture } \\
\hline $\mathrm{pH}$ & $\mathrm{Ec} \mathrm{dS} / \mathrm{cm}$ & $\mathrm{P}$ & $\mathrm{K}$ & $\mathrm{CaCO}_{3}$ & Clay & Silt & Sand & \\
\hline 7.8 & 0.69 & 0.20 & 265.2 & 13.1 & 60.0 & 28.5 & 11.5 & Clay \\
\hline
\end{tabular}

\subsection{Measurements and Data Collection}

Matured fruits were harvested by hand picking, and twelve plants were randomly tagged per plot for determination of plant height, number of leaves per plant, number of days to $50 \%$ flowering, number of fruits per plant, fruit length, fruit yield per plant $(\mathrm{kg})$, and fruit yield per hectare $(\mathrm{t} / \mathrm{ha})$.

\subsection{Fertilizers Analysis}

Chicken manure was taken before applying to the soil and analyzed (Table 2). In the end of experiment analysis of soil samples was made (Table 5). 
Table 2. Chemical and physical analysis of chicken manure

\begin{tabular}{lll}
\hline Test name & Result & Unit \\
\hline $\mathrm{pH}$ & 7.1 & \\
$\mathrm{EC}$ & 3.7 & $\mathrm{dS} / \mathrm{m}$ \\
$\mathrm{N}$ & 2.5 & $\mathrm{wt} / \mathrm{wt} \%$ \\
$\mathrm{P}_{2} \mathrm{O}_{5}$ & 1.6 & $\mathrm{wt} / \mathrm{wt} \%$ \\
$\mathrm{~K}_{2} \mathrm{O}$ & 1.7 & $\mathrm{wt} / \mathrm{wt} \%$ \\
$\mathrm{Ash}$ & 10.0 & $\%$ \\
Moisture & 32.5 & $\%$ \\
Organic matter & 57.5 & $\%$ \\
$\mathrm{C} / \mathrm{N}$ & $13: 1$ & \\
$\mathrm{Cd}<0.002$ & $\mathrm{ppm}$ & \\
\hline
\end{tabular}

Table 3. Chemical and physical properties of NPK

\begin{tabular}{|c|c|c|c|c|c|c|c|c|c|c|}
\hline \multicolumn{11}{|c|}{ Properties of chemical fertilizers \% } \\
\hline \multicolumn{6}{|c|}{ NPK } & \multicolumn{5}{|c|}{ Trace elements } \\
\hline Total N & $\mathrm{NH}_{4}$ & $\mathrm{NO}_{3}$ & Uric $\mathrm{N}$ & Total $\mathrm{P}_{2} \mathrm{O}_{5}$ & Total $\mathrm{K}_{2} \mathrm{O}$ & $\mathrm{Fe}$ & $\mathrm{Zn}$ & $\mathrm{Cu}$ & $\mathrm{Mn}$ & $\mathrm{B}$ \\
\hline 15 & 3 & 7.2 & 4.8 & 15 & 30 & 0.02 & 0.01 & 0.005 & 0.01 & 0.005 \\
\hline
\end{tabular}

\subsection{Statistical Analysis}

The data were analyzed according to randomized complete block design. Differences between treatment means were compared at $\mathrm{P}=5 \%$ with ANOVA to find the significant differences and LSDs were used to compare the plots. The statistical analysis of the data was realized using SAS program. (SAS, 2001).

\section{Results}

\subsection{Effect of NPK and Chicken Manure on Yield and Yield Components}

All treatments indicated significant differences $(\mathrm{P}=0.05)$ among them for yield and yield components except for fruit length (Table 4). The plant height, number of leaves per plant, number of fruits per plant, fruit yield $(\mathrm{kg} / \mathrm{plant})$, and fruit yield $(\mathrm{t} / \mathrm{ha})$ were significantly $(\mathrm{P}=0.05)$ affected by adding of different doses of NPK and chicken manure.

\subsubsection{Plant Height}

NPK (T3) gave the highest plant height $(86 \mathrm{~cm})$ followed by chicken manure $(\mathrm{T} 2=76 \mathrm{~cm})$, and control $(\mathrm{T} 1=54$ $\mathrm{cm}$ ) (Figure1).

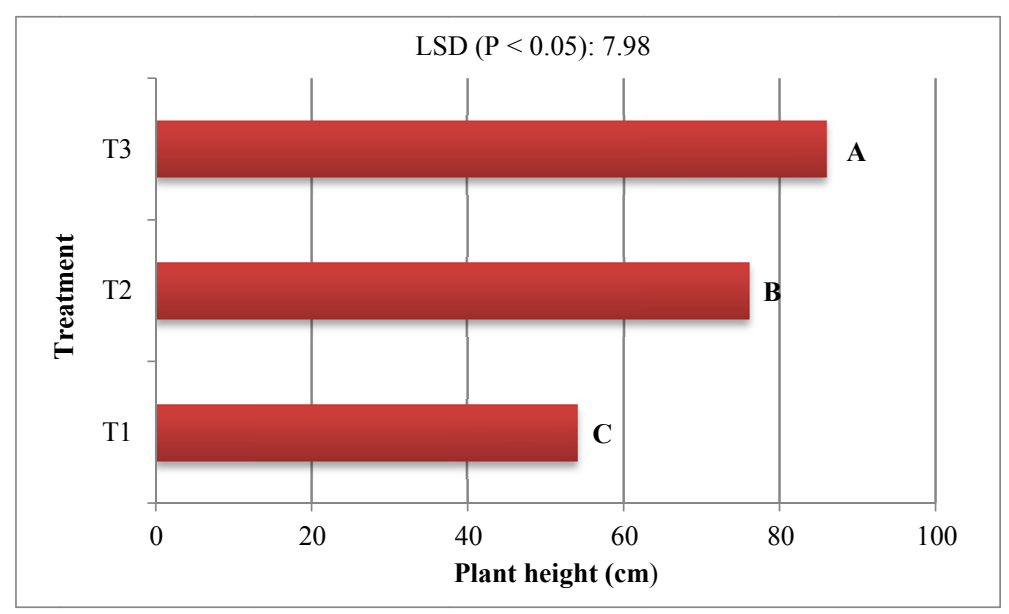

Figure 1. Effect of the treatments on the plant height $(\mathrm{cm})$;

$\mathrm{T} 1=$ Control, $\mathrm{T} 2=$ Chicken manure, $\mathrm{T} 3=\mathrm{NPK}$ 


\subsubsection{Number of Leaves per Plant and Number of Fruits per Plant}

Table 4 showed that T3 gave highest number of leaves per plant 33.5, T2 gave 27.083, and T1 gave 19.33. The highest number of fruits per plant 59.42 was recorded by T3, followed by T2 $=49.25$, and T1 $=38.67$ (Figure 2 ).

Table 4. Effect of the treatments on the yield and yield components

\begin{tabular}{llllllll}
\hline Treatment & $\begin{array}{l}\text { Plant height } \\
(\mathbf{c m})\end{array}$ & $\begin{array}{l}\text { No. of } \\
\text { leaves/plant }\end{array}$ & $\begin{array}{l}\text { No. of days to } \\
\mathbf{5 0 \%} \text { flowering }\end{array}$ & $\begin{array}{l}\text { No. of } \\
\text { fruits/plant }\end{array}$ & Fruit length & $\begin{array}{l}\text { Fruit yield } \\
(\mathbf{k g} / \mathbf{p l a n t})\end{array}$ & $\begin{array}{l}\text { Fruit yield } \\
\text { (t/ha) }\end{array}$ \\
\hline Control & $54.0 \mathrm{c}$ & $19.33 \mathrm{c}$ & $56.0 \mathrm{c}$ & $38.67 \mathrm{c}$ & $9.5 \mathrm{a}$ & $1.98 \mathrm{c}$ & $7.90 \mathrm{c}$ \\
Chicken manure & $76.0 \mathrm{~b}$ & $27.0 \mathrm{~b}$ & $50.33 \mathrm{~b}$ & $49.25 \mathrm{~b}$ & $9.5 \mathrm{a}$ & $3.67 \mathrm{~b}$ & $14.67 \mathrm{~b}$ \\
NPK & $86.0 \mathrm{a}$ & $33.5 \mathrm{a}$ & $45.83 \mathrm{a}$ & $59.42 \mathrm{a}$ & $9.5 \mathrm{a}$ & $5.75 \mathrm{a}$ & $23.00 \mathrm{a}$ \\
\hline
\end{tabular}

Note. Means within a columns and rows followed with the same letter are not significantly different from each other at $5 \%$ probability level.

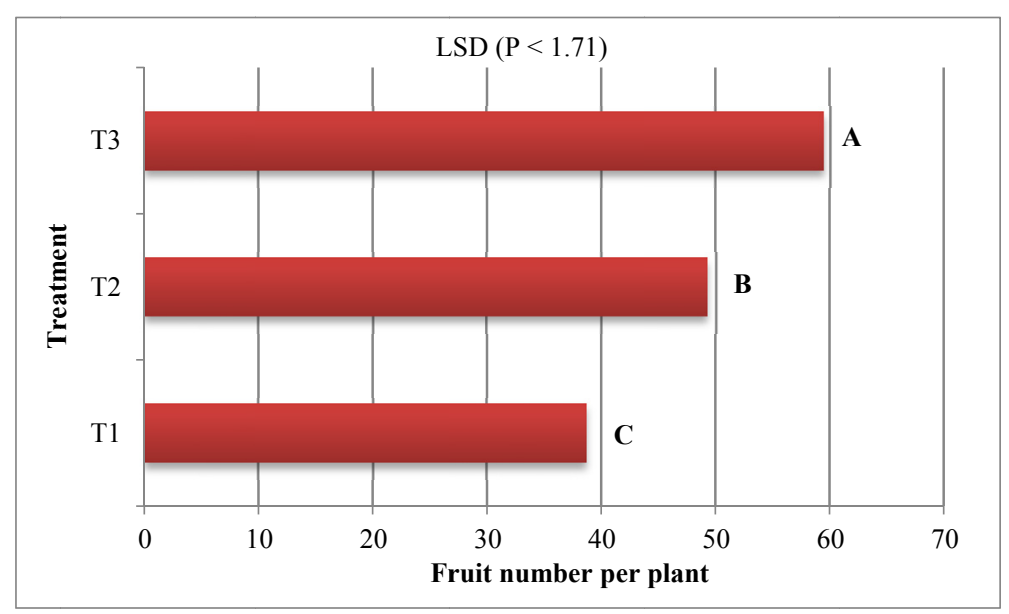

Figure 2. Effect of the treatments on the number of fruits per plant; $\mathrm{T} 1=$ Control, $\mathrm{T} 2=$ Chicken manure, $\mathrm{T} 3=\mathrm{NPK}$

\subsubsection{Fruit Yield}

T3 showed the highest fruit yield (kg/plant) 5.75, T2 gave 3.67, and T1 gave 1.98 (Figure 3). The same result recorded for fruit yield (t/ha), i.e. T3 gave 23.00 followed by T2 gave 14.67, and T1 gave 7.93 (Figure 4).

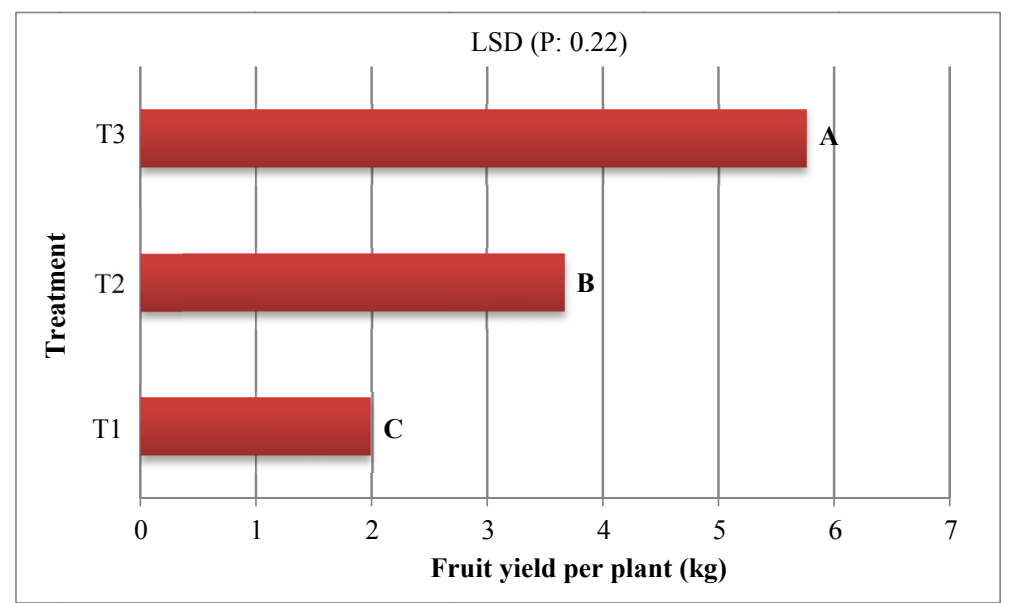

Figure 3. Effect of the treatments on the fruit yield (kg per plant); $\mathrm{T} 1=$ Control, $\mathrm{T} 2=$ Chicken manure, $\mathrm{T} 3=\mathrm{NPK}$ 


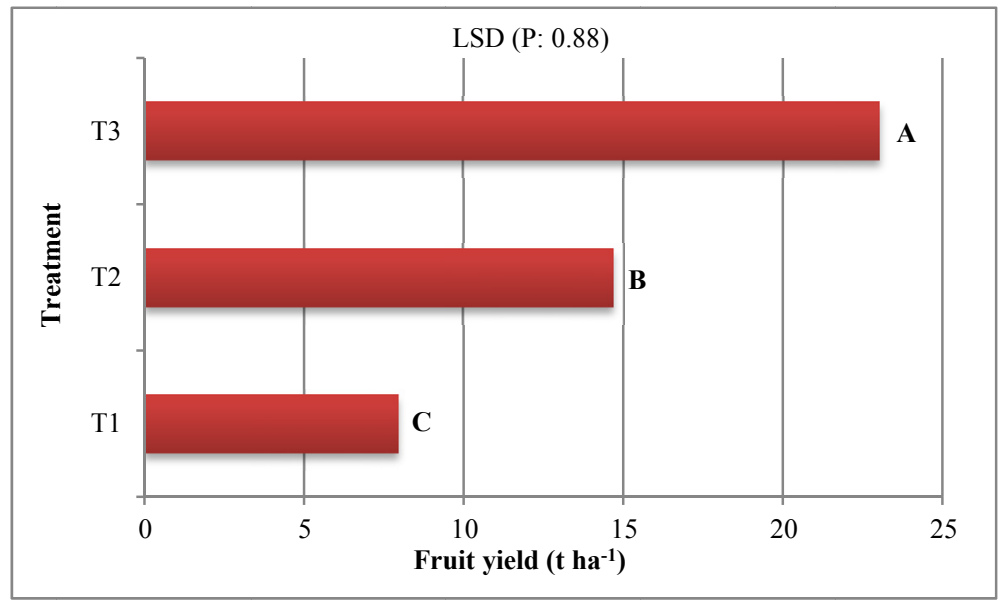

Figure 4. Effect of the treatments on the fruit yield ( $\mathrm{t}$ per ha); $\mathrm{T} 1=$ Control, $\mathrm{T} 2=$ Chicken manure, $\mathrm{T} 3=\mathrm{NPK}$

\subsection{Effect of NPK and Chicken Manure on Nutrient Contents of Sweet Pepper Shoots}

Table 5 showed that application of NPK recorded higher concentration of N, K, Mg, Fe, Mn, Zn, and Cu in plant tissues than application of chicken manure, while chicken manure gave higher concentration of $\mathrm{Ca}$ only.

Table 5. Effect of treatments on mineral contents of sweet pepper shoots

\begin{tabular}{|c|c|c|c|c|c|c|c|c|c|}
\hline Treatment & $\mathbf{N}$ & $\mathbf{P}$ & $\mathbf{K}$ & $\mathbf{C a}$ & Mg & $\mathbf{F e}$ & Mn & $\mathbf{Z n}$ & $\mathrm{Cu}$ \\
\hline & \multicolumn{5}{|c|}{------------------------------ \% } & \multicolumn{4}{|c|}{----------------------- ppm -----------------------. } \\
\hline Control & $1.5 \mathrm{c}$ & $0.37 \mathrm{a}$ & $1.96 \mathrm{~b}$ & $0.31 \mathrm{~b}$ & $0.47 \mathrm{a}$ & $37.88 b$ & $5.57 \mathrm{~b}$ & $21.53 \mathrm{a}$ & $9.0 \mathrm{a}$ \\
\hline Chicken manure & $2.0 \mathrm{~b}$ & $0.31 \mathrm{~b}$ & $1.72 \mathrm{c}$ & $0.34 \mathrm{a}$ & $0.35 \mathrm{c}$ & $5.68 \mathrm{c}$ & $3.43 \mathrm{c}$ & $10.55 \mathrm{c}$ & $4.45 \mathrm{c}$ \\
\hline NPK+ TE & $3.0 \mathrm{a}$ & $0.31 \mathrm{~b}$ & $2.24 \mathrm{a}$ & $0.24 \mathrm{c}$ & $0.42 \mathrm{~b}$ & $56.0 \mathrm{a}$ & $7.20 \mathrm{a}$ & $15.55 \mathrm{~b}$ & $6.30 \mathrm{~b}$ \\
\hline
\end{tabular}

Note. Means within a columns and rows followed with the same letter are not significantly different from each other at $5 \%$ probability level.

\subsection{Effect of Chicken Manure and NPK on Soil Properties}

Phosphor (P) and potassium (K) contents of soil increased significantly in plots treated with chicken manure (28.9), (294.0) and NPK (27.0), (275.4) as compared with control (14.1), (210.3), respectively, whereas there was a slight decrease in $\mathrm{pH}(7.8$ to 7.7$)$ for chicken manure and $\mathrm{pH}$ remain constant for NPK and control plots (7.8) Table 6.

Table 6. Effect of chicken manure and NPK on soil properties

\begin{tabular}{|c|c|c|c|c|c|}
\hline & \multicolumn{2}{|c|}{ Extract } & \multicolumn{2}{|c|}{ ppm } & \multirow{2}{*}{$\begin{array}{r}\% \\
\mathrm{CaCO}_{3} \\
\end{array}$} \\
\hline & pH & EC (dS/m) & $\mathbf{P}$ & $\mathbf{K}$ & \\
\hline Chicken manure & 7.7 & 1.83 & 28.9 & 294.0 & 11.1 \\
\hline Chemical fertilizer & 7.8 & 2.18 & 127.0 & 275.4 & 8.2 \\
\hline Control (without fertilizers) & 7.8 & 1.17 & 14.1 & 210.3 & 11.1 \\
\hline
\end{tabular}

\section{Discussion}

\subsection{Effect of Chicken Manure and NPK on Yield and Yield Component}

Our results for plant height, fruit yield per plant $(\mathrm{kg})$, and fruit yield per hectare $(\mathrm{t} / \mathrm{ha})$ agreed with the results of Omogoye (2015), who reported that NPK gave longer plant height, higher fruit yield per plant $(\mathrm{kg})$, and higher fruit yield (t/ha) of pepper as compared with cow manure. Ibrahim (2013) reported that adding of nitrogen and potassium increased plant height and yield of pepper and tomato over control. Awodun (2007) found that (250 
$\mathrm{kg} / \mathrm{ha}$ ) gave longer plant height, higher leave number, fruit number/plant, fruit weight/plant as compared with 10 t/ha goat manure, Adeola et al. (2007) observed that plants treated with NPK recorded the shortest number of days to $50 \%$ flowering when compared with poultry manure and control treatments, they also observed that NPK gave higher number of fruits/plant than poultry manure and control treatments cassava and pepper intercropping. Alex and Eliakira (2014), found that NPK gave higher plant height, fruit number/plant, fruit length, fruit yield $(\mathrm{kg} / \mathrm{plant})$, and fruit yield (t/ha) than organic fertilizers and control of sweet pepper. Ewulo et al. (2007) found that cow manure gave higher plant height, leave number/plant, fruit number/plant, fruit yield $(\mathrm{kg} / \mathrm{plant})$ than organic fertilizers and control. Alaba (2011) observed that NPK increased plant height, leaves/plant, and fruit yield $(\mathrm{t} / \mathrm{ha})$ when compared with poultry manure.

On the other hand, the following results were on conflict with our results; Ahsanur Rahman et al. (2012) found that cow manure gave higher plant height, fruit number $/$ plant, fruit yield $(\mathrm{kg} / \mathrm{plant})$, and fruit yield $(\mathrm{t} / \mathrm{ha})$ than NPK fertilizers of pepper. Ikeh (2012) said that poultry manure increased plant height, number of fruits/plant, fruit length, fruit yield per plant $(\mathrm{kg})$, and fruit yield (t/ha) and reduced number of days to $50 \%$ flowering as compared with control of pepper. Kawthar (2011) reported that chicken manure increased number of fruits/plant, fruit length, and fruit yield (t/ha) as compared with NPK, and she also said that NPK increased plant height, number of leaves/plant and reduced number of days to $50 \%$ flowering as compared with chicken manure and control of sweet pepper. Jesusa et al. (2007) observed that chicken manure gave higher yield than covenantal method (chemical fertilizer) of hot pepper.

Nitrogen has an important role on synthesis of chlorophyll, protein, enzymes, which increase photosynthesis and promote vegetative growth result in increasing assimilates which express into yield. This explains the response of pepper to inorganic fertilizers rather than organic $s$ and gave more yields in case of inorganic in our experiment. Also response of vegetable crops to inorganic fertilizers is faster than its response to organic in my opinion. On the other hand, we conducted our experiment in greenhouse, which gave more yield than open field planting.

\subsection{Effect of NPK and Chicken Manure on Nutrient Contents of Sweet Pepper Shoots}

The effects of chicken manure and NPK fertilizers on mineral concentration of plant's tissues were determined. The results reported in Table 5 showed that there were significant differences with chicken manure and NPK application on mineral concentration of plant tissues. NPK application increased plant tissue concentration of N, $\mathrm{K}, \mathrm{Fe}$, and $\mathrm{Mn}$ and this may increase the yield and yield components significantly as compared with chicken manure and control treatments, whereas NPK application did not increase $\mathrm{P}, \mathrm{Mg}, \mathrm{Zn}$, and $\mathrm{Cu}$ concentration, our result agreed with Ibrahim (2013) who observed that adding N statistically increased the yield and N, and $\mathrm{K}$ concentration, and disagreed with his result which showed that plant tissue $\mathrm{P}$ and $\mathrm{Zn}$ concentration was affected significantly by the $\mathrm{N}$ addition. Our result also coincide with Omogoye (2015), who reported that chicken manure and NPK application increased N content in pepper leaves from $2.7 \%$ (control) to $4.60 \%$ (cow dung), and (NPK) gave $5.10 \%$, and $\mathrm{K}$ content behaved the same.

Also harmony results were observed by Shahein et al. (2015), and Alabi (2006), they reported that N, and K\% increased in sweet pepper leaves when plants were fertilized by chicken manure.

\subsection{Effect of Chicken Manure and NPK on Soil Properties}

According to the results of this study we can conclude that chicken manure at rate of $15 \mathrm{t} / \mathrm{ha}$, had beneficial effect on the increasing $(\mathrm{P})$ and $(\mathrm{K})$ contents of soil. Besides these, growth and fruit yield of sweet pepper were also enhanced. NPK also increased $(\mathrm{P})$ and $(\mathrm{K})$ contents of soil.

\section{Conclusion}

In the end of experiment, we conclude that sweet pepper responded to organic and inorganic fertilizers under greenhouse conditions. In case of mineral contents in plant tissues, we conclude that application of NPK and chicken manure fertilizers affect significantly mineral concentration and also showed a significant effect on $\mathrm{P}$ and $\mathrm{K}$ soil contents. This may lead to an increase in the yield of sweet pepper. Finally NPK (15:15:30) with trace elements at $100 \mathrm{Kg} / \mathrm{ha}$ and chicken manure at rate of $15 \mathrm{t} / \mathrm{ha}$ had a significant increase on yield of sweet pepper. In spite of NPK gave higher yield than chicken manure, we may prefer to use chicken manure because it is cheaper than NPK and it is environmental friendly. Further studies are recommended to evaluate the effect of chemical and organic fertilizers on pepper. 


\section{Acknowledgements}

The author expresses special thanks to the deanship of scientific research, Albalqa applied university, Jordan Soil for financial support, and also I would like to express my appreciation to Prof. Mazen Ateyyat for his help in statistical analysis.

\section{References}

Adeola, R. G., Tijani-Eniola, H., \& Makinde, E. A. (2011). Ameliorate the Effects of Poultry Manure and NPK Fertilizer on the Performance of Pepper relay cropped with Two Cassava Varieties. Global Journal of Science Frontier Research, 11(9), 7-13.

Ahsanur Rahman, M., Matiur Rahman, M., Begum, M. F., \& Firoz Alam, M. (2012). Effect of bio compost, cow dung compost and NPK fertilizers on growth, yield and yield components of chili. International Journal of Biosciences, 2(1), 51-55.

Alabi, D. A. (2006). Effect of Fertilizer Phosphorus and Poultry Droppings Treatments on Growth and Nutrient Components of Pepper (Capsicum annum L.) African Journal of Biotechnology, 5(8), 671-677.

Alaba, T. F., Oyeboade, S. A., Gbenga, S. A., Olufemi, T. A., Catherine, A. A., \& Esther, A. A. (2011). Evaluation of Growth and Yield of (Capsicum annum L.) Var 'Nsukka Yellow' under Different Fertilizer Regimes in Ibadan, South-western Nigeria. The African Journal of Plant Science and Biotechnology, 5(1), 46-49.

Alex, A. R., \& Eliakira, K. (2014). Effect of NPK and Minjingu Mazao Fertilizers on the Performance of Sweet Pepper in Morogoro, Tanzania. Direct Research Journal of Agriculture and Food Science, 2(11), 179-183.

Aliyu, L. (2000). The effect of organic and mineral fertilizers on growth, yield and composition of pepper (Capsicum annuum L.). Biological Agriculture and Horticulture, 18(1), 29-36. https://doi.org/10.1080/ 01448765.2000 .9754862

Aliyu, L. (2002). Growth and Yield of Pepper (Capsicum annuum L.) as affected by Nitrogen and Phosphorus Application and Plant Density. Crop Research, 23(3), 467-475.

Aliyu, L., Yusuf, Y., \& Ahmad, M. K. (1996). Response of pepper to fertilizers: Growth yield and yield components as affected by nitrogen and phosphorus levels. In A. Adebanjo (Ed.), Proc. 14th Hortson Conference Ago-Iwoye, April 1-4, 1996 (pp. 43-50).

Awodun, M. A., Omonjo, L. I., \& Ojeniyi, S. O. (2007). Effect of goat dung and NPK fertilizer on soil and leaf nutrient content growth and yield of pepper. International Journal of Soil Science, 2(2), 142-147. https://doi.org/10.3923/ijss.2007.142.147

Belel, M. D., Saidu, M. S., \& Sajo, A. A. (2011). Effect of land preparation and weeding regime on the yield of sweetpepper (Capsicum annuum L.) in Mubi, Adamawa State. Journal of Agron., 10, 62-67. https://doi.org/ $10.3923 /$ ja.2011.62.67

Bosland, P. W., \& Vatava, E. J. (2000). Peppers, vegetables and spices capsicum (p. 204). CABI publishing, Wallingford, UK. Retrieved from http://trove.nla.gov.au/version/218033243

Dasgan, H. Y., Kusvuran, S., \& Ortas, I. (2008). Responses of soilless grown tomato plants to arbuscular mycorrhizal fungal (Glomus fasciculatum) colonization in re-cycling and open systems. African Journal of Biotechnology, 7(20), 3606-3613.

Dauda, N. S., Ajayi, F. A., \& Ndor, E. (2008). Growth and yield of watermelon (Citrullus lanatus) as affected by poultry manure application. Journal of Agriculture and Social Sciences, 4(3), 121-124.

Dauda, N. S., Aliyu, L., \& Chiezey, U. F. (2005). Effect of seedling age at transplant and poultry manure on fruit yield and nutrient composition of garden egg (Solanum gilo L.) varieties. Journal of Tropical Biosciences, $5(2), 38-41$.

Ewulo, B. S., Hassan, K. O., \& Ojeniyi, S. O. (2007). Comparative effect of cow dung manure on soil and leaf nutrient and yield of pepper. International Journal of Agricultural Research, 2, 1043-1048. https://doi.org/ 10.3923/ijar.2007.1043.1048

Ibrahim, O. (2013). Influences of nitrogen and potassium fertilizer rates on pepper and tomato yield and nutrient uptake under field conditions. Academic Journals, 8(23), 1048-1055.

Ikeh, A. O., Ndaeyo, U. N., Uduak, I. G., Iwo, G. A., Ugbe, L. A., Udoh, E. I., \& Effiong, G. S. (2012). Growth and yield responses of pepper (Capsicum frutescens L.) to varied poultry manure rates in UYO, Southern Nigeria. Journal of Agricultural and Biological Science, 7(9), 735-742. 
Islam, M., Saha, S., Akand, M. H., \& Rahim, M. A. (2011). Effect of spacing on the growth and yield of sweet pepper (Capsicum annuum L.). Journal of Central European Agriculture, 12(2), 328-335. https://doi.org/ 10.5513/JCEA01/12.2.917

Jesusa, C. L., Cassel, G., Gilbert, Q., Norman, L., James, C., \& Benjamin, C. L. (2007). Effect of organic and chemical fertilizers on growth and yield of hot pepper, and insect pests and their natural enemies. Subtropical Plant Science, 59, 75-84.

Juroszek, P., \& Tsai, H. H. (2009). Yields of organically grown sweet pepper cultivars and lines during the hot-wet and cool-dry season in the tropics. Horticultural Technology, 19(2), 418-422.

Kabura, B. H., Musa, B., \& Odo, P. E. (2008). Evaluation of the yield components and yield of onion (Allium cepa L.) pepper (Capsicum annum L.) intercrop in the Sudan Savannah. Journal of Agronomy, 7, 88-92. https://doi.org/10.3923/ja.2008.88.92

Khan, M. S. I., Roy, S. S., \& Pall, K. K. (2010). Nitrogen and phosphorus efficiency on the growth and yield attributes of Capsicum. Academic Journal of Plant Sciences, 3(2), 71-78.

Kauthar, K. (2014). Performance of sweet pepper (Capsicum annuum L.) varieties as influenced by nitrogen and poultry manure fertilization in Sudan savanna (M.Sc./AGRIC/02712/2010-2011, thesis).

Malgorzata, B., \& Georgios, K. (2008). Physiological response and yield of pepper plants to organic fertilization. Journal of Central European Agriculture, 9(4), 715-722.

Omogoye, A. M. (2015). Efficacy of NPK and cow dung combinations on performance of chili pepper (Capiscum annuиm L.) and their influence on soil properties. Journal of Agriculture and Veterinary Science, 8(7), 31-35.

Shahein, M. M., El-Sayed, S. F., Hassan, H. A., \& Abou-El-Hassan, S. (2015). Producing sweet pepper organically using different sources of organic fertilizers under plastic house conditions (pp. 72-78). International Conference on Advances in Agricultural, Biological \& Environmental Sciences (AABES-2015) July 22-23, 2015, London, UK.

Statistical Analysis System. (2001). SAS/STAT User's Guide for Personal Computers. Release 6.12, SAS Instt. Inc., Cary, N.C., SA.

\section{Copyrights}

Copyright for this article is retained by the author(s), with first publication rights granted to the journal.

This is an open-access article distributed under the terms and conditions of the Creative Commons Attribution license (http://creativecommons.org/licenses/by/4.0/). 